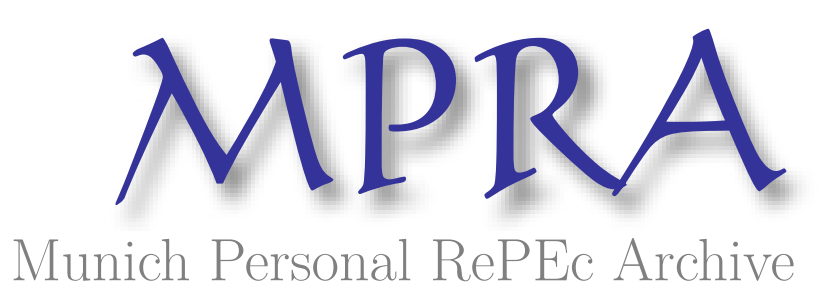

\title{
How are the Children of Visible Minority Immigrants Doing in the Canadian Labour Market?
}

Grady, Patrick

Global Economics Ltd.

27 January 2011

Online at https://mpra.ub.uni-muenchen.de/28503/

MPRA Paper No. 28503, posted 31 Jan 2011 14:01 UTC 


\section{GLOBAL ECONOMICS LTD.}

How are the Children of Visible Minority Immigrants Doing in the Canadian Labour Market?

By

Patrick Grady

Global Economics Working Paper 2011-1

January 27, 2011 


\begin{abstract}
:
This paper examines the performance of the children of immigrants $\left(2^{\text {nd }}\right.$ generation immigrants) to Canada using data from the 2006 Census. As the composition of immigration inflows has shifted after 1980 from the traditional European source countries to the Third World, the analysis focuses on the labour market performance of $2^{\text {nd }}$ generation visible minority immigrants of whom there were 398 thousand aged 15 and over who reported employment income in the Census.
\end{abstract}

An encouraging fact revealed by the data is that $2^{\text {nd }}$ generation visible minority immigrants are becoming more highly educated than $2^{\text {nd }}$ generation non-visible minority immigrants and than non-immigrants -46.2 per cent of $2^{\text {nd }}$ generation visible minority between 25 and 44 earning employment had earned university certificates or degrees compared to 31 per cent of non-visible minority $2^{\text {nd }}$ generation immigrants and 24 per cent of non-immigrants in the same age groups.

But, while $2^{\text {nd }}$ generation visible minority immigrants obtained more education than $2^{\text {nd }}$ generation non-visible minority immigrants and non-immigrants, their performance as a group did not measure up in the labour market. In the 25 to 44 age group, accounting for the largest number of $2^{\text {nd }}$ generation visible minority immigrants, they only earned on average $\$ 39,814$, whereas $2^{\text {nd }}$ generation non-visible minority immigrants earned $\$ 45,352$ and non-immigrants 40,358.

The labour market performance varies significantly among different visible minority groups. $2^{\text {nd }}$ generation Chinese immigrants in the 25 to 44 age group actually earned $\$ 48,098$, which was actually more than $2^{\text {nd }}$ generation non-visible minority immigrants and non-immigrants. Because of the large number of Chinese included as $2^{\text {nd }}$ generation immigrants, this buoyed up the overall average and masked the unfortunate fact that many other visible minority groups are doing much worse than average overall and falling short of non-immigrants.

A troubling aspect of the performance of $2^{\text {nd }}$ generation immigrants, except for Chinese and Japanese, is the extent to which they earn substantially less than non-immigrants and especially non-visible minority immigrants for any given level of education.

The paper thus provides no grounds for complacency that the children of the recent, particularly non-Asian visible minority, immigrants who are performing so poorly in Canada's labour market will catch up with non-immigrant groups, particularly given that their parents are currently performing much worse than earlier visible minority immigrants in the labour market. And it is unlikely that $2^{\text {nd }}$ generation visible minority immigrants as a group will earn enough to make up for the current earnings shortfall experienced by their parents in recent cohorts of underperforming immigrants.

Furthermore, the lower earnings of many visible minority groups for any given level of education are likely to continue be used as justification for more affirmative action programs. This will adversely affect the non-visible minority and non-immigrant population, and could become a source of increasing social tension. 
JEL Classification Codes: J23 - Labour demand; J24 - Human Capital; Skills; Occupational Choice; Labour Productivity; J61 - Geographic mobility, immigrant workers.

Keywords: wages, $2^{\text {nd }}$ generation immigrants to Canada, immigration policy, human capital 


\section{Introduction}

A series of Statistics Canada studies (Picot, 2008; Picot and Sweetman, 2005; Picot and Hou, 2008) has highlighted the poor and deteriorating performance of recent immigrants in labour markets and the resulting growth of poverty among immigrants. These adverse trends combined with the progressive social benefits offered by the Canadian welfare state call into question the economic benefits to Canada that are supposed to come from an open immigration policy that admits among the highest levels of new immigrants per capita in the industrialized world.

The most plausible defence of continued high mass immigration in the face of the emergence of these unpleasant facts is that, while it is undeniable that recent immigrants are not doing very well, their children and grandchildren born and educated in Canada will make it in the Canadian labour market and do as well as or better than other Canadians. And this has generally been the case in past periods when Canada has absorbed large numbers of new immigrants.

Nevertheless, everyone must admit that it is not easy to predict how the children of immigrants, let alone their grandchildren, will do based on the past experience of immigrants. After the 1980s, the source of Canada's immigration shifted from the traditional countries of Western and Eastern Europe to the Third World. The largest portion of the new immigrants started to come from Asia, the Middle East, Africa and Latin America, which are regions of the world with cultures, languages and religions that are quite different from the majority of Canadians of European background. And most of the new immigrants can be classified as visible minorities. Based on their experience once in Canada, these groups have been judged to have unique challenges competing in Canadian labour markets. In recognition, Canadian governments have introduced affirmative action programs, which are called "employment equity" programs in Canada.

As visible minorities are expected to continue to be the largest source of new immigrants to Canada, it is important to look at how their children born in Canada $\left(2^{\text {nd }}\right.$ generation immigrants) are doing in the Canadian labour market as measured by their average employment incomes. And as immigrants from different countries and regions are doing quite differently in the labour market, it is also useful to consider the different performance of the children of those from these different places (at least to the extent that it is possible using the published data on the employment income of $2^{\text {nd }}$ generation immigrants from different source regions from the 2006 Census).

This study consequently examines the average education levels and incomes of three groups of people: $2^{\text {nd }}$ generation visible minority immigrants (defined as those so classifying themselves in the 2006 Census as visible minority and as children of immigrants), $2^{\text {nd }}$ generation non-visible minority immigrants (similarly defined as those so classifying themselves), and non-immigrants (defined as those born in Canada, which also includes as a small portion $2^{\text {nd }}$ generation immigrants). 


\section{The Evidence}

Statistics Canada has posted tabulations of the data on the employment statistics by geography, work activity status, generation status, visible minority status, age group, education, and sex by from the 2006 Census. These data are taken from the 20-per-cent Census sample and include the numbers in the groups, and their median employment income and average employment income reported for 2005. ${ }^{1}$ The analysis presented here uses the data on average employment income for total work activity including both parttime and full time. For purposes of analysis, it is broken down by educational level, visible minority group, age group, and gender. A caveat is in order. The categories for visible minority are unfortunately very aggregative and are not necessarily indicative of ethnic origin, but they are all that is available in the free published data tabulations. ${ }^{2}$

\section{The Number of $2^{\text {nd }}$ Generation Immigrants}

The number of $2^{\text {nd }}$ generation visible minority immigrants 15 and over reporting employment income is not yet a large proportion of the total Canadian population (Table 1A). But it still totals 398 thousand, which should be large enough to provide an idea of how the children of visible minority immigrants born in Canada are doing in the labour market. However, the numbers are much smaller for $2^{\text {nd }}$ generation immigrants aged 25 and over. This is the group who should have completed their education and joined the labour force in a fully trained capacity (only 186 thousand between 25 and 44 years of age and 20 thousand between 45 and 64 Table 1B). This is because the large inflow of visible minority immigrants is only a post-1980 phenomenon and many years are required before their children can take their full place in the Canadian labour market. The numbers also become even smaller when they are broken down by gender into men and women (Table 1C) and when they are further disaggregated by visible minority class (based on country or region, or skin colour). This leaves many cells in the tables with few observations and limits the extent to which it is possible to draw firm conclusions about some aspects of the labour market performance of $2^{\text {nd }}$ generation immigrants.

\section{Educational Attainment}

An encouraging fact revealed by the data is that $2^{\text {nd }}$ generation visible minority immigrants are becoming more highly educated than $2^{\text {nd }}$ generation non-visible minority immigrants and than non-immigrants -46.2 per cent of $2^{\text {nd }}$ generation visible minority between 25 and 44 earning employment income had earned university certificates or degrees compared to 31 per cent of non-visible minority $2^{\text {nd }}$ generation immigrants and 24 per cent of non-immigrants in the same age groups (Table $2 \mathrm{~B}$ ). Moreover, some $2^{\text {nd }}$ generation visible minority immigrants are getting much more education than others -64 per cent of $2^{\text {nd }}$ generation Korean immigrants between 25 and 44 have a university degree or certificate, 60.3 per cent of Chinese, 56.8 per cent of West Asians, 52.2 per cent of South Asians, and 47.7 per cent of Japanese.

The same holds true for advanced degrees -13.5 per cent of $2^{\text {nd }}$ generation visible minority between 25 and 44 earning employment had earned university certificates, diplomas or degrees above the bachelor's compared to 9.5 per cent of non-visible minority $2^{\text {nd }}$ generation immigrants and 6.9 per cent of non-immigrants in the same age 
groups (Table 2B). Again the educational attainment of some groups stand out -20.8 per cent of Koreans in the 25-to-44 age group have more than a bachelor's degree, 18.9 per cent of South Asians, 15.6 per cent of Chinese, and 14.5 per cent of Southeast Asians. These relatively high levels of educational achievement might reflect the high value traditionally put on education by these cultures.

On the other hand, there are some visible minority groups of $2^{\text {nd }}$ generation immigrants that are getting significantly less education than non-visible minority and non-immigrants groups. Only 11.3 per cent of Latin Americans, 17.2 per cent of Southeast Asians and 19.7 per cent of Blacks earned university certificates or degrees. And only 5.4 per cent of Latin Americans, 6.7 per cent of Filipinos had university certificates, diplomas or degrees above the bachelor's.

Interestingly, the level of education of women $2^{\text {nd }}$ generation visible minority immigrants was even higher than men as it also was for $2^{\text {nd }}$ generation non-visible minority immigrants and non-immigrants, which as a category also includes $2^{\text {nd }}$ generation immigrants (Table 2C).

\section{Average Employment Earnings}

While $2^{\text {nd }}$ generation visible minority immigrants obtained more education than $2^{\text {nd }}$ generation non-visible minority immigrants and non-immigrants, their performance as a group in aggregate comes up slightly short in the labour market. In the 25-to-44 age group, accounting for the largest number of 2nd generation visible minority immigrants, they only earned on average $\$ 39,814$, whereas $2^{\text {nd }}$ generation non-visible minority immigrants earned $\$ 45,352$ and non-immigrants $\$ 40,358$ (Table 3B). ${ }^{3}$ And in the 45-to64 age group, $2^{\text {nd }}$ generation visible minority immigrants earned $\$ 49,460$ less than the $\$ 53,778$ for $2^{\text {nd }}$ generation non-visible minority immigrants, but more than the $\$ 47,016$ earned by non-immigrants. However, it would be misleading to make too much of this difference as the results are only for a relatively small number of individuals who are predominantly of Chinese, and Japanese origin.

The labour market performance varies significantly among visible minority groups. $2^{\text {nd }}$ generation Chinese immigrants in the 25 -to-44 age group actually earned $\$ 48,098$, which was more than $2^{\text {nd }}$ generation non-visible minority immigrants and non-immigrants. Because of the large number of Chinese included as $2^{\text {nd }}$ generation visible minority immigrants, this buoyed the overall average. Other smaller visible minority groups in the 25-to-44 age group that outperformed non-immigrants, but not $2^{\text {nd }}$ generation non-visible minority immigrants, were Japanese $(\$ 45,028)$, Korean $(\$ 42,143)$, and South Asian (\$40,717). Arabs, many of whom were Lebanese, earned $\$ 39,511$ or about average. On the other hand, Blacks $(\$ 34,631)$ and Latin Americans $(\$ 31,468)$ experienced the largest earnings shortfalls in average employment earnings amounting to 22 and 19 per cent respectively.

While $2^{\text {nd }}$ generation visible minority women earn substantially less than men, they do better than men relative to non-immigrants (Table 3C). 
A troubling aspect of the performance of $2^{\text {nd }}$ generation immigrants, except for Chinese and Japanese, is the extent to which they earn substantially less than non-immigrants and especially non-visible minority immigrants for any given educational level. Some will undoubtedly be inclined to attribute these differences in labour market performance to discrimination. To make a convincing case, they will have to explain why only some visible minority groups are the victims of discrimination and not others. Nevertheless, this will not stop them from using the lower earnings of visible minorities as a justification to put more pressure on governments to strengthen affirmative action programs. The downside of this is, of course, that such programs will have an adverse affect on the employment prospects of those who are not visible minorities, thus encouraging increased social conflict, especially between visible minorities and nativeborn Canadians.

Another cause for concern is that the current labour market performance of $2^{\text {nd }}$ generation visible minority immigrants may not be a reliable indicator of the labour market performance of $2^{\text {nd }}$ generation visible minority immigrants in the future. The reason this might be the case is that the current group of $2^{\text {nd }}$ generation visible minority immigrants of prime labour force age are the children of cohorts of visible minority immigrants who came to Canada in much smaller numbers than are being admitted currently before immigration was liberalized and who were able to perform much better in the labour market than the post-1990 cohorts for whom the earnings deterioration was observed to be most marked. ${ }^{4}$

The current poor performance of visible minority immigrants in the labour market is likely to lead to future problems because there is evidence that the income of parents can adversely affect the incomes of children. For instance, Burton and Phipps (2009, p.4-5) have found that children coming from low- income families exhibited considerable "stickiness" of position in the income distribution and that this was exacerbated by being "non-white" as are the greater majority of recent immigrants. And immigrants coming to Canada during the current period of high unemployment could suffer from "scarring" and have the long term prospects of themselves and even their children damaged.

\section{Conclusions}

The good news from the 2006 Census is that the Canadian-born children of some visible minority immigrants, particularly Koreans, Chinese and West Asians, are getting more education than non-visible minority $2^{\text {nd }}$ generation immigrants and non-immigrants.

The evidence from the 2006 Census, however, provides no grounds for complacency that the children of the recent non-Asian visible minority immigrants who are performing so poorly in Canada's labour market will catch up with non-immigrant groups in their earnings, or do as well as the descendants of non-visible minority immigrants who are still continuing to out-earn non-immigrant groups. This is because of the relatively poor performance of particular visible minority groups and because of the risk that the poor economic performance of the current cohort of visible minority immigrants who will be the parents of future $2^{\text {nd }}$ generation visible minority immigrants will compromise the future educational attainments of their descendants. 
The main premise underlying Canada's open immigration policy, namely that immigrants, or at least their children, regardless of where they come from in the world, will eventually perform economically as well as everybody else with respect to their earnings, is thus at this point very much still open to question.

The incomes earned by immigrants and their children are the most important indicator of the success of Canada's immigration policy. These incomes equal their direct contribution to output as well as their claim on output. The incomes of non-immigrants are not affected directly by the immigrants' participation in the economy. However, because of the progressive income tax system and the universality of social benefits in Canada's welfare state, immigrants and their children with below average incomes impose a fiscal burden on existing Canadian residents while those with above average incomes provide a fiscal benefit. To truly provide a net fiscal benefit to Canada from a continuation of high levels of immigration, the children of the current cohort of immigrants will need to earn enough to pay through taxation for the government pension and health programs required to take care of their parents after retirement. And this will likely be very costly indeed as these parents are expected to have low market income after retirement because of the impact of their current low earnings and abbreviated work lives resulting from their late arrival to Canada on their future retirement pensions and savings.

Considered in the light of this analysis, the findings of this paper suggest that it is unlikely that Canada's current immigration policy, if maintained, will be a source of net fiscal benefits in the future, but rather that it is more likely that it will be a continuing source of fiscal burden.

And it is unfortunate that the lower earnings of many visible minority groups for any given level of education will likely give rise to social tensions. Differences in earnings will be held up as indicators of discrimination that can only be countered through the introduction of more and strengthened affirmative action programs. And, if affirmative action is viewed as reverse discrimination, the non-visible minority population, including non-immigrants, who are adversely affected, can be expected to be resentful, particularly after having welcomed so many visible minority immigrants into the country. 


\section{Footnotes}

1. The relevant web page for the tabulations can be found at http://www12.statcan.gc.ca/census-recensement/2006/dp-pd/tbt/Rpeng.cfm?TABID $=1 \& \mathrm{LANG}=\mathrm{E} \& \mathrm{APATH}=3 \& \mathrm{DETAIL}=0 \& \mathrm{DIM}=0 \& \mathrm{FL}=\mathrm{A} \& \mathrm{FRE}$ $\mathrm{E}=0 \& \mathrm{GC}=0 \& \mathrm{GK}=0 \& \mathrm{GRP}=1 \& \mathrm{PID}=96280 \& \mathrm{PRID}=0 \& \mathrm{PTYPE}=88971,97154 \& \mathrm{~S}$ $=0 \&$ SHOWALL $=0 \&$ SUB $=0 \&$ Temporal $=2006 \&$ THEME $=72 \& \mathrm{VID}=0 \& \mathrm{VNAME}$ $\mathrm{E}=\& \mathrm{VNAMEF}=$

2. A finer breakdown by source country is provided in the 2006 Census Public Use Microdata File (PUMF). However, it is not a very reliable source of information on the employment income of $2^{\text {nd }}$ generation visible minority immigrants because it only incorporates a sample of 2.7 per cent of the Canadian population, which is much smaller than the 20 per cent sample used in the tabulations used here.

3. There is a question if the results for the 25 to 44 age group could be distorted by the age composition of the different three groups in the overall category. For instance, if the visible minority $2^{\text {nd }}$ generation immigrants were on average younger than the non-visible minority $2^{\text {nd }}$ generation immigrants, then their earnings level could be lower because the had less experience and were not a far advanced in their careers. Unfortunately, the earnings data from the 20 per cent sample is only published for the whole 25 to 44 age group and not be any subgroups that would shed light on the question. To answer this question, it would be necessary to have access to the full 20 per cent sample and not just the tabulations.

4. The data and some analysis of the poor labour market of recent immigrants by country or region of origin are presented in Grady (2010). 


\section{References}

Burton, Peter and Shelley Phipps (2009). "The Prince and the Pauper: Movement of Children Up and Down the Canadian Income Distribution, 1994-2004." Canadian Labour Market and Skills Researcher Network, Working Paper No. 31.

Grady, Patrick (2010) "An Analysis of the Underlying Causes of the Poor Performance of Recent Immigrants Using the 2006 Census PUMF and Some Observations on Their Implications for Immigration Policy." Global Economics Working Paper 2010-2.

<www.global-economics.ca/empin_recent_immigrants.pdf $>$

Grubel, Herbert (2005) "Immigration and the Welfare State in Canada: Growing Conflicts, Constructive Solutions." Fraser Institute Public Policy Sources, Number 84, September.

Picot, Garnett (2008). Immigrant Economic and Social Outcomes in Canada: Research and Data Development at Statistics Canada. Catalogue No. 11F0019M No. 319, Statistics Canada.

Picot, Garnett, and Arthur Sweetman (2005). The Deteriorating Economic Welfare of Immigrants and Possible Causes: Update 2005. Catalogue No. 11F0019MIE2005262. Statistics Canada.

Picot, Garnett, and Feng Hou (2008). Immigrant Characteristics, the IT Bust, and Their Effect on Entry Earnings of Immigrants. Catalogue No. 11F0019MWE2008315. Statistics Canada. <http://www.statcan.gc.ca/pub/11f0019m/11f0019m2008315-eng.pdf > 
Table 1A: Numbers of Individuals 15 Years and Over Reporting Average Employment Income in 2005

\begin{tabular}{|c|c|c|c|c|c|}
\hline & $\begin{array}{l}\text { Certificate } \\
\text { or } \\
\text { Diploma } \\
\text { below } \\
\text { Bachelors }\end{array}$ & $\begin{array}{l}\text { University } \\
\text { Certificate } \\
\text { or Degree }\end{array}$ & $\begin{array}{l}\text { Bachelor's } \\
\text { Degree }\end{array}$ & $\begin{array}{l}\text { University } \\
\text { Certificate, } \\
\text { Diploma or } \\
\text { Degree } \\
\text { Above } \\
\text { Bachelors }\end{array}$ & Total \\
\hline \multicolumn{6}{|l|}{$\begin{array}{l}\text { 2nd Generation } \\
\text { Immigrants Total Age } \\
\text { Groups }\end{array}$} \\
\hline Chinese & 61,880 & 41,775 & 31,895 & 9,880 & 103,655 \\
\hline South Asian ${ }^{1}$ & 66,460 & 30,995 & 21,075 & 9,920 & 97,460 \\
\hline Black & 65,590 & 16,140 & 11,930 & 4,210 & 81,735 \\
\hline Filipino & 21,530 & 6,285 & 5,200 & 1,085 & 27,815 \\
\hline Latin American & 13,065 & 1,670 & 1,295 & 375 & 14,735 \\
\hline Southeast Asian² & 11,995 & 2,505 & 1,840 & 665 & 14,505 \\
\hline Arab & 10,695 & 3,570 & 2,475 & 1,090 & 14,265 \\
\hline West Asian³ & 2,020 & 790 & 545 & na & 2,805 \\
\hline Korean & 3,890 & 3,020 & 2,145 & 880 & 6,910 \\
\hline Japanese & 7,125 & 3,505 & 2,475 & 1,025 & 10,635 \\
\hline Visible Minority n.i.e & 6,690 & 1,735 & 1,315 & 415 & 8,430 \\
\hline Multiple Visible Minority ${ }^{4}$ & 10,990 & 3,880 & 2,855 & 1,025 & 14,870 \\
\hline Total Visible Minority & 281,930 & 115,870 & 85,050 & 30,820 & 397,805 \\
\hline Not a Visible Minority & $1,831,750$ & 582,375 & 383,450 & 198,925 & $2,414,130$ \\
\hline Total Non - Immigrant & $11,594,450$ & $2,684,055$ & $1,829,780$ & 854,270 & $14,278,500$ \\
\hline
\end{tabular}

Source: Statistics Canada, Tabulations from 2006 Census.

Notes:

1. South Asian includes, for example, 'East Indian', 'Pakistani', 'Sri Lankan', etc.

2. Southeast Asian includes, for example, 'Vietnamese', 'Cambodian', 'Malaysian', 'Laotian', etc.

3. West Asian includes, for example, 'Iranian', 'Afghan', etc.

4. Multiple visible minority includes respondents who reported more than one visible minority group by checking two or more mark-in circles, e.g., 'Black' and 'South Asian'. 
Table 1B: Numbers of Individuals 15 Years and Over Reporting Average Employment Income in 2005 by Age Group

\begin{tabular}{|c|c|c|c|c|c|}
\hline & $\begin{array}{l}\text { Certificate } \\
\text { or Diploma } \\
\text { below } \\
\text { Bachelors }\end{array}$ & $\begin{array}{l}\text { University } \\
\text { Certificate } \\
\text { or Degree }\end{array}$ & $\begin{array}{l}\text { Bachelo } \\
\text { r's } \\
\text { Degree }\end{array}$ & $\begin{array}{l}\text { University } \\
\text { Certificate, } \\
\text { Diploma or } \\
\text { Degree } \\
\text { Above } \\
\text { Bachelors }\end{array}$ & Total \\
\hline \multicolumn{6}{|l|}{$\begin{array}{l}\text { 2nd Generation } \\
\text { Immigrants } 25 \text { to } 44 \\
\text { Years }\end{array}$} \\
\hline Chinese & 19,460 & 29,520 & 21,880 & 7,640 & 48,980 \\
\hline South Asian & 21,715 & 23,730 & 15,140 & 8,590 & 45,445 \\
\hline Black & 28,635 & 13,010 & 9,395 & 3,615 & 41,650 \\
\hline Filipino & 8,760 & 4,905 & 3,960 & 945 & 13,665 \\
\hline Latin American & 4,405 & 1,330 & 1,015 & 310 & 5,735 \\
\hline Southeast Asian & 2,025 & 1,540 & 1,025 & 515 & 3,560 \\
\hline Arab & 4,235 & 2,625 & 1,745 & 880 & 6,860 \\
\hline West Asian & 400 & 525 & 330 & 0 & 925 \\
\hline Korean & 1,385 & 2,465 & 1,665 & 800 & 3,850 \\
\hline Japanese & 2,195 & 2,000 & 1,480 & 520 & 4,195 \\
\hline Visible Minority n.i.e & 3,230 & 1,390 & 1,020 & 365 & 4,620 \\
\hline Multiple Visible Minority & 3,815 & 2,965 & 2,105 & 860 & 6,785 \\
\hline Total Visible Minority & 100,270 & 86,005 & 60,765 & 25,235 & $\begin{array}{r}186,270 \\
1,051,97\end{array}$ \\
\hline Not a Visible Minority & 727,730 & 324,240 & $\begin{array}{r}224,185 \\
1,041,88\end{array}$ & 100,055 & $\begin{array}{r}0 \\
5,954,77\end{array}$ \\
\hline Total Non - Immigrant & $4,501,695$ & $1,453,075$ & 5 & 411,190 & 0 \\
\hline \multicolumn{6}{|l|}{$\begin{array}{l}\text { 2nd Generation } \\
\text { Immigrants } 45 \text { to } 64 \\
\text { Years }\end{array}$} \\
\hline Chinese & 6,060 & 4,420 & 3,040 & 1,380 & 10,480 \\
\hline South Asian & 1,355 & 410 & na & na & 1,765 \\
\hline Black & 2,535 & 545 & 350 & na & 3,080 \\
\hline Filipino & na & na & na & na & na \\
\hline Latin American & 260 & na & na & na & 320 \\
\hline Southeast Asian & na & na & na & na & na \\
\hline Arab & 440 & na & na & na & 630 \\
\hline West Asian & na & na & na & na & na \\
\hline Korean & na & na & na & na & na \\
\hline Japanese & 1,825 & 770 & 490 & 285 & 2,600 \\
\hline Visible Minority n.i.e & na & na & na & na & na \\
\hline Multiple Visible Minority & na & na & na & na & 290 \\
\hline Total Visible Minority ${ }^{1}$ & 13,310 & 6,680 & 4,425 & 2,255 & 19,990 \\
\hline Not a Visible Minority & 605,340 & 191,650 & 112,585 & 79,060 & $\begin{array}{r}796,990 \\
5,085,80\end{array}$ \\
\hline Total Non - Immigrant & $4,139,270$ & 946,530 & 570,800 & 375,725 & 0 \\
\hline
\end{tabular}

Source: Statistics Canada, Tabulations from 2006 Census. Notes:

1. Total Visible Minority is less than the sum of categories because some of data is not provided. 
Table 1C: Numbers of Individuals 15 Years and Over Reporting Average Employment Income in 2005 by Gender

2nd Generation

Immigrants Men

Chinese

South Asian

Black

Filipino

Latin American

Southeast Asian

Arab

West Asian

Korean

Japanese

Visible Minority n.i.e

Multiple Visible Minority

Total Visible Minority

Not a Visible Minority

Total Non - Immigrant

2nd Generation

Immigrants Women

Chinese

South Asian

Black

Filipino

Latin American

Southeast Asian

Arab

West Asian

Korean

Japanese

Visible Minority n.i.e

Multiple Visible Minority

Total Visible Minority

Not a Visible Minority

Total Non - Immigrant

\section{Certificate \\ or

Diploma
below
Bachelors

Bachelors

\author{
University \\ Certificate, \\ Diploma \\ or Degree \\ Above \\ Bachelors Total
}

University

Certificate Bachelor's

Degree

$$
\begin{array}{r}
15,385 \\
9,615 \\
4,355 \\
2,170 \\
540 \\
810 \\
1,175 \\
275 \\
945 \\
1,245 \\
460 \\
1,200 \\
38,175 \\
182,310 \\
838,725
\end{array}
$$

$1,268,530$

16,505

11,465

7,575

3,030

750

1,030

1,300

275

1,200

1,230

855

1,650

46,875

201,135

991,055

$\begin{array}{rr}5,040 & 53,725 \\ 4,480 & 49,875 \\ 1,510 & 39,890 \\ 435 & 14,015 \\ \text { na } & 7,360 \\ 285 & 7,140 \\ 590 & 7,480 \\ \text { na } & 1,330 \\ 350 & 3,440 \\ 550 & 5,820 \\ \text { na } & 4,175 \\ 460 & 7,035 \\ 14,065 & 201,290 \\ 100,930 & 1,258,770 \\ 429,805 & 7,424,245\end{array}$

4,840

49,925

$5,440 \quad 47,580$

$2,700 \quad 41,840$

$650 \quad 13,795$

$250 \quad 7,375$

$380 \quad 7,360$

$500 \quad 6,785$

na $\quad 1,480$

$525 \quad 3,470$

$475 \quad 4,810$

$270 \quad 4,250$

$565 \quad 7,835$

$16,750 \quad 196,515$

$98,000 \quad 1,155,360$

$424,465 \quad 6,854,260$ 
Table 2A: Distribution of Numbers Reporting Average Employment Income in 2005 by Education (\%)

\begin{tabular}{|c|c|c|c|c|c|}
\hline $\begin{array}{l}\text { 2nd Generation } \\
\text { Immigrants Total Age } \\
\text { Groups }\end{array}$ & $\begin{array}{l}\text { Certificate } \\
\text { or } \\
\text { Diploma } \\
\text { below } \\
\text { Bachelors }\end{array}$ & $\begin{array}{l}\text { University } \\
\text { Certificate } \\
\text { or Degree }\end{array}$ & $\begin{array}{l}\text { Bachelor's } \\
\text { Degree }\end{array}$ & $\begin{array}{l}\text { University } \\
\text { Certificate, } \\
\text { Diploma } \\
\text { or Degree } \\
\text { Above } \\
\text { Bachelors }\end{array}$ & Total \\
\hline Chinese & 59.7 & 40.3 & 30.8 & 9.5 & 100.0 \\
\hline South Asian & 68.2 & 31.8 & 21.6 & 10.2 & 100.0 \\
\hline Black & 80.2 & 19.7 & 14.6 & 5.2 & 100.0 \\
\hline Filipino & 77.4 & 22.6 & 18.7 & 3.9 & 100.0 \\
\hline Latin American & 88.7 & 11.3 & 8.8 & 2.5 & 100.0 \\
\hline Southeast Asian & 82.7 & 17.3 & 12.7 & 4.6 & 100.0 \\
\hline Arab & 75.0 & 25.0 & 17.4 & 7.6 & 100.0 \\
\hline West Asian & 72.0 & 28.2 & 19.4 & na & 100.0 \\
\hline Korean & 56.3 & 43.7 & 31.0 & 12.7 & 100.0 \\
\hline Japanese & 67.0 & 33.0 & 23.3 & 9.6 & 100.0 \\
\hline Visible Minority n.i.e & 79.4 & 20.6 & 15.6 & 4.9 & 100.0 \\
\hline Multiple Visible Minority & 73.9 & 26.1 & 19.2 & 6.9 & 100.0 \\
\hline Total Visible Minority & 70.9 & 29.1 & 21.4 & 7.7 & 100.0 \\
\hline Not a Visible Minority & 75.9 & 24.1 & 15.9 & 8.2 & 100.0 \\
\hline Total Non - Immigrant & 81.2 & 18.8 & 12.8 & 6.0 & 100.0 \\
\hline
\end{tabular}

Source: Statistics Canada, Tabulations from 2006 Census. 
Table 2B: Distribution of Numbers Reporting Average Employment Income in 2005 by Education and Age Group (\%)

\begin{tabular}{|c|c|c|c|c|c|}
\hline \multicolumn{6}{|l|}{$\begin{array}{l}\text { 2nd Generation } \\
\text { Immigrants } 25 \text { to } 44 \\
\text { Years }\end{array}$} \\
\hline Chinese & 39.7 & 60.3 & 44.7 & 15.6 & 100.0 \\
\hline South Asian & 47.8 & 52.2 & 33.3 & 18.9 & 100.0 \\
\hline Black & 68.8 & 31.2 & 22.6 & 8.7 & 100.0 \\
\hline Filipino & 64.1 & 35.9 & 29.0 & 6.9 & 100.0 \\
\hline Latin American & 76.8 & 23.2 & 17.7 & 5.4 & 100.0 \\
\hline Southeast Asian & 56.9 & 43.3 & 28.8 & 14.5 & 100.0 \\
\hline Arab & 61.7 & 38.3 & 25.4 & 12.8 & 100.0 \\
\hline West Asian & 43.2 & 56.8 & 35.7 & na & 100.0 \\
\hline Korean & 36.0 & 64.0 & 43.2 & 20.8 & 100.0 \\
\hline Japanese & 52.3 & 47.7 & 35.3 & 12.4 & 100.0 \\
\hline Visible Minority n.i.e & 69.9 & 30.1 & 22.1 & 7.9 & 100.0 \\
\hline Multiple Visible Minority & 56.2 & 43.7 & 31.0 & 12.7 & 100.0 \\
\hline Total Visible Minority & 53.8 & 46.2 & 32.6 & 13.5 & 100.0 \\
\hline Not a Visible Minority & 69.2 & 30.8 & 21.3 & 9.5 & 100.0 \\
\hline Total Non - Immigrant & 75.6 & 24.4 & 17.5 & 6.9 & 100.0 \\
\hline \multicolumn{6}{|l|}{$\begin{array}{l}\text { 2nd Generation } \\
\text { Immigrants } 45 \text { to } 64 \\
\text { Years }\end{array}$} \\
\hline Chinese & 57.8 & 42.2 & 29.0 & 13.2 & 100.0 \\
\hline South Asian & 76.8 & 23.2 & na & na & 100.0 \\
\hline Black & 82.3 & 17.7 & 11.4 & na & 100.0 \\
\hline Filipino & na & na & na & na & na \\
\hline Latin American & 81.3 & na & na & na & 100.0 \\
\hline Southeast Asian & na & na & na & na & na \\
\hline Arab & 69.8 & na & na & na & 100.0 \\
\hline West Asian & na & na & na & na & na \\
\hline Korean & na & na & na & na & na \\
\hline Japanese & 70.2 & 29.6 & 18.8 & 11.0 & 100.0 \\
\hline Visible Minority n.i.e & na & na & na & na & na \\
\hline Multiple Visible Minority & na & na & na & na & na \\
\hline Total Visible Minority & 66.6 & 33.4 & 22.1 & 11.3 & 100.0 \\
\hline Not a Visible Minority & 76.0 & 24.0 & 14.1 & 9.9 & 100.0 \\
\hline Total Non - Immigrant & 81.4 & 18.6 & 11.2 & 7.4 & 100.0 \\
\hline
\end{tabular}

\begin{tabular}{llll}
$\begin{array}{l}\text { Certificate } \\
\text { or }\end{array}$ & & \multicolumn{1}{c}{$\begin{array}{l}\text { University } \\
\text { Certificate, }\end{array}$} \\
$\begin{array}{l}\text { Diploma } \\
\text { Diploma }\end{array}$ & \multicolumn{1}{c}{$\begin{array}{l}\text { University } \\
\text { or Degree }\end{array}$} & \\
below & $\begin{array}{l}\text { Certificate } \\
\text { Bachelors }\end{array}$ or Degree & $\begin{array}{l}\text { Bachelor's } \\
\text { Above }\end{array}$ & Degree \\
Bachelors Total
\end{tabular}

39.7

52.2

23.2

43.3

47.7

30.1

43.7

46.2

30.8

24.4
23.2
17.7
na
na
na
na
29.6
na
24.0

11.2

\author{
University \\ Diploma \\ or Degree \\ Above
}

$\begin{array}{ll}15.6 & 100.0 \\ 18.9 & 100.0\end{array}$

$8.7 \quad 100.0$

$6.9 \quad 100.0$

$5.4 \quad 100.0$

$14.5 \quad 100.0$

$12.8 \quad 100.0$

na $\quad 100.0$

$20.8 \quad 100.0$

100.0

100.0

$13.5 \quad 100.0$

100.0

100.0

00.0

100.0

na

0.0

0.0

na

a na na

00.0

100.0

Source: Statistics Canada, Tabulations from 2006 Census. 
Table 2C: Distribution of Numbers Reporting Average Employment Income in 2005 by Education and Gender (\%)

2nd Generation

Certificate
or
Diploma
below
Bachelors

$\begin{array}{ll}\text { University } & \\ \text { Certificate } & \text { Bachelor's } \\ \text { or Degree } & \text { Degree }\end{array}$

University
Certificate,
Diploma
or Degree
Above
Bachelors Total

Immigrants Men

Chinese

62.0

38.0

71.7

28.3

85.3

14.7

81.4

18.6

90.9

9.1

15.3

84.6

23.5

72.6

27.1

62.4

37.6

69.1

30.9

Japanese

Visible Minority n.i.e

Multiple Visible Minority

85.4

14.6

23.7

26.0

74.0

22.5

77.5

Not a Visible Minority

Total Non - Immigrant

17.1

28.6

19.3

10.9

15.5

7.3

11.3

15.7

20.7

27.5

21.4

11.0

17.1

19.0

14.5

11.3

$\begin{array}{rr}9.4 & 100.0 \\ 9.0 & 100.0 \\ 3.8 & 100.0 \\ 3.1 & 100.0 \\ \text { na } & 100.0 \\ 4.0 & 100.0 \\ 7.9 & 100.0 \\ \text { na } & 100.0 \\ 10.2 & 100.0 \\ 9.5 & 100.0 \\ \text { na } & 100.0 \\ 6.5 & 100.0 \\ 7.0 & 100.0 \\ 8.0 & 100.0 \\ 5.8 & 100.0\end{array}$

2nd Generation

Immigrants Women

Chinese

57.2

33.1

24.1

South Asian

64.5

42.8

18.1

24.6

75.4

26.7

22.0

86.4

13.6

10.2

19.2

14.0

73.4

26.7

Arab

West Asian

71.3

28.7

Korean

50.3

49.7

19.2

18.6

34.6

Japanese

35.4

25.6

26.5

Visible Minority n.i.e

Multiple Visible Minority

73.4

20.1

71.7

28.3

21.1

32.4

23.9

74.1

25.9

Not a Visible Minority

Total Non - Immigrant

79.3

20.7

17.4

14.5

$\begin{array}{rr}9.7 & 100.0 \\ 11.4 & 100.0 \\ 6.5 & 100.0 \\ 4.7 & 100.0 \\ 3.4 & 100.0 \\ 5.2 & 100.0 \\ 7.4 & 100.0 \\ \text { na } & 100.0 \\ 15.1 & 100.0 \\ 9.9 & 100.0 \\ 6.4 & 100.0 \\ 7.2 & 100.0 \\ 8.5 & 100.0 \\ 8.5 & 100.0 \\ 6.2 & 100.0\end{array}$


Table 3A: Average Employment Income in 2005 (\$)

2nd Generation
Immigrants Total Age
Groups
Chinese
South Asian
Black
Filipino
Latin American
Southeast Asian
Arab
West Asian
Korean
Japanese
Visible Minority n.i.e
Multiple Visible Minority
Total Visible Minority
Not a Visible Minority
Total Non - Immigrant

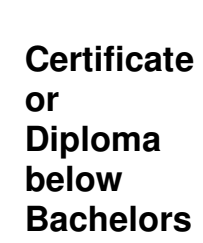

University

Certificate

or Degree

\author{
University \\ Certificate, \\ Diploma \\ or Degree \\ Above \\ Bachelors Total
}

$\begin{array}{rrrrr}21,545 & 50,505 & 45,602 & 66,334 & 33,216 \\ 17,495 & 41,861 & 36,849 & 52,510 & 25,245 \\ 18,582 & 38,676 & 35,975 & 46,331 & 22,550 \\ 18,896 & 36,084 & 35,147 & 40,569 & 22,781 \\ 16,705 & 33,144 & 31,326 & 39,343 & 18,568 \\ 12,750 & 34,294 & 30,408 & 45,092 & 16,474 \\ 19,932 & 45,436 & 44,221 & 48,185 & 26,314 \\ 15,359 & 36,785 & 33,418 & \text { na } & 21,371 \\ 17,494 & 41,489 & 38,934 & 47,736 & 27,984 \\ 27,568 & 52,610 & 46,539 & 67,263 & 35,826 \\ 20,948 & 42,979 & 36,860 & 62,447 & 25,481 \\ 17,448 & 42,599 & 38,465 & 54,108 & 24,010 \\ 18,917 & 44,364 & 40,263 & 55,680 & 26,329 \\ 33,314 & 64,527 & 58,756 & 75,651 & 40,844 \\ 30,720 & 61,237 & 55,384 & 73,775 & 36,457\end{array}$

Source: Statistics Canada, Tabulations from 2006 Census. 
Table 3B: Average Employment Income in 2005 by Age Group (\$)

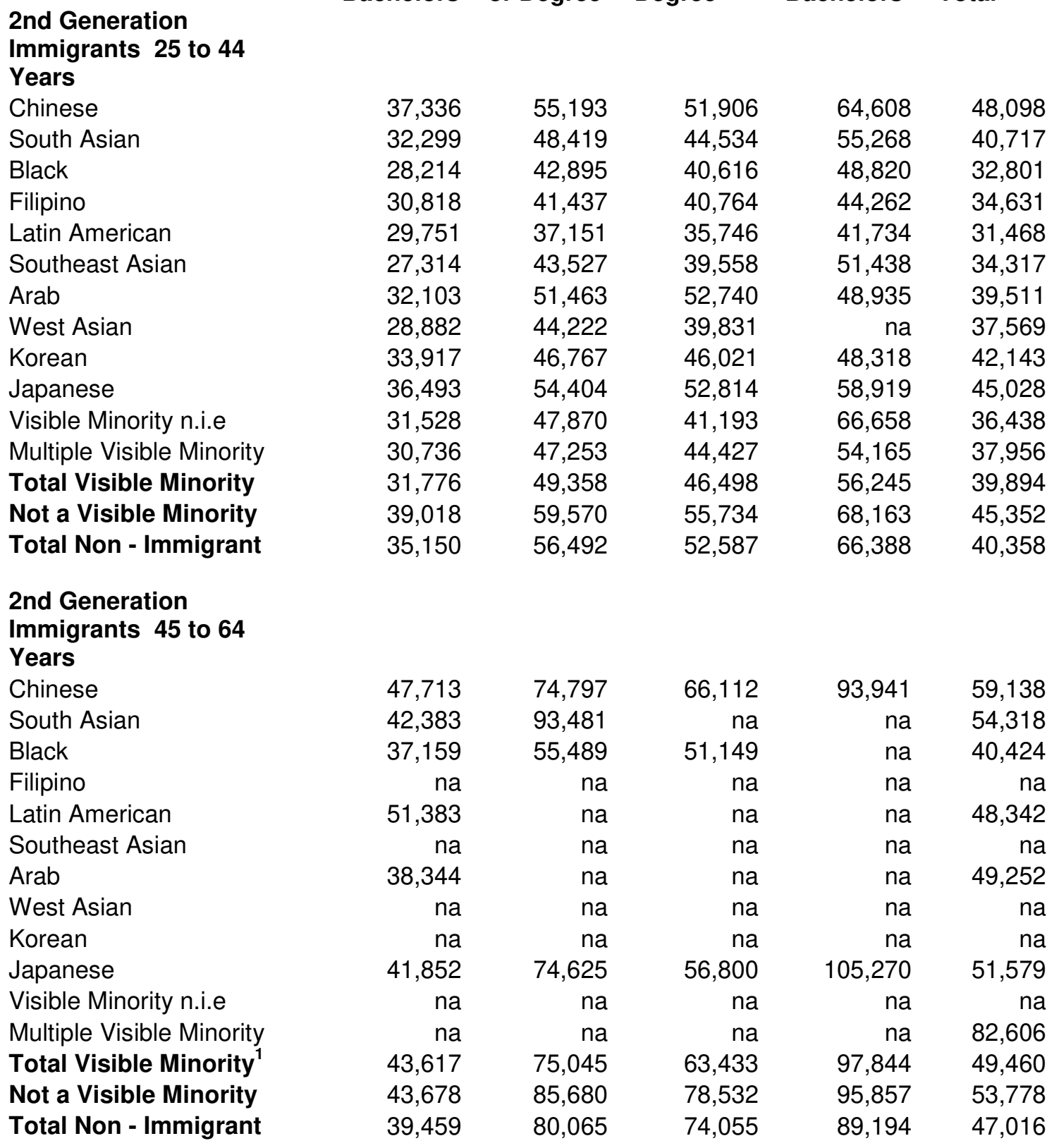

Certificate
or
Diploma
below
Bachelors

University

Certificate

Certificate

Bachelor's

Degree

University

Certificate,

Diploma

or Degree

Above

2nd Generation

Years

Chinese

South Asian

Black

Filipino

Latin American

Southeast Asian

Arab

West Asian

Korean

Japanese

Visible Minority n.i.e

Multiple Visible Minority

Not a Visible Minority

Not a Visible Minority

2nd Generation

Immigrants 45 to 64

Years

Chinese

South Asian

Black

Filipino

Latin American

Southeast Asian

Arab

West Asian

Korean

Japanese

Visible Minority n.i.e

Multiple Visible Minority

Not a Visible Minority

Total Non - Immigrant

Source: Statistics Canada, Tabulations from 2006 Census.

Note:

1. Multiple Visible Minority is a very small group for the 45 to 64 age group and its total is

unduly influenced by some very high values. The median is $\$ 41,978$, which is half the mean. 
Table 3C: Average Employment Income in 2005 by Gender (\$)

\begin{tabular}{|c|c|c|c|c|c|}
\hline \multicolumn{6}{|l|}{$\begin{array}{l}\text { 2nd Generation } \\
\text { Immigrants Men }\end{array}$} \\
\hline Chinese & 23,867 & 58,745 & 51,732 & 80,165 & 37,126 \\
\hline South Asian & 19,425 & 49,474 & 42,604 & 64,214 & 27,916 \\
\hline Black & 20,264 & 44,365 & 41,705 & 52,052 & 23,808 \\
\hline Filipino & 20,360 & 38,338 & 36,239 & 48,726 & 23,702 \\
\hline Latin American & 19,837 & 36,234 & 34,678 & na & 21,328 \\
\hline Southeast Asian & 13,800 & 35,984 & 31,754 & 48,050 & 17,207 \\
\hline Arab & 23,475 & 57,956 & 58,717 & 56,442 & 31,604 \\
\hline West Asian & 17,805 & 38,373 & 32,701 & na & 23,400 \\
\hline Korean & 19,769 & 51,959 & 47,652 & 63,521 & 31,893 \\
\hline Japanese & 32,002 & 64,895 & 55,218 & 86,730 & 42,176 \\
\hline Visible Minority n.i.e & 24,026 & 58,111 & 44,438 & na & 28,980 \\
\hline Multiple Visible Minority & 19,699 & 51,838 & 46,509 & 65,744 & 27,299 \\
\hline Total Visible Minority & 21,080 & 52,495 & 46,583 & 68,542 & 29,234 \\
\hline Not a Visible Minority & 39,897 & 82,960 & 75,970 & 95,585 & 49,587 \\
\hline Total Non - Immigrant & 36,946 & 78,673 & 71,565 & 92,544 & 44,076 \\
\hline \multicolumn{6}{|l|}{$\begin{array}{l}\text { 2nd Generation } \\
\text { Immigrants Women }\end{array}$} \\
\hline Chinese & 18,839 & 42,623 & 39,889 & 51,943 & 29,009 \\
\hline South Asian & 15,244 & 35,514 & 32,023 & 42,870 & 22,445 \\
\hline Black & 16,768 & 35,429 & 32,680 & 43,137 & 21,351 \\
\hline Filipino & 17,245 & 34,489 & 34,366 & 35,067 & 21,845 \\
\hline Latin American & 13,417 & 31,078 & 28,910 & 37,573 & 15,814 \\
\hline Southeast Asian & 11,683 & 32,980 & 29,350 & 42,868 & 15,763 \\
\hline Arab & 15,867 & 33,225 & 31,167 & 38,541 & 20,488 \\
\hline West Asian & 13,111 & 35,438 & 34,131 & na & 19,548 \\
\hline Korean & 14,698 & 33,623 & 32,072 & 37,166 & 24,107 \\
\hline Japanese & 21,830 & 39,647 & 37,749 & 44,575 & 28,146 \\
\hline Visible Minority n.i.e & 17,431 & 34,832 & 32,777 & 41,363 & 22,044 \\
\hline Multiple Visible Minority & 15,296 & 35,663 & 32,609 & 44,603 & 21,057 \\
\hline Total Visible Minority & 16,491 & 37,687 & 35,116 & 44,881 & 23,354 \\
\hline Not a Visible Minority & 25,814 & 47,073 & 43,152 & 55,120 & 31,318 \\
\hline Total Non - Immigrant & 23,673 & 45,612 & 41,690 & 54,770 & 28,204 \\
\hline
\end{tabular}

\begin{tabular}{|c|c|c|c|}
\hline $\begin{array}{l}\text { Certificate } \\
\text { or } \\
\text { Diploma } \\
\text { oelow } \\
\text { Bachelors }\end{array}$ & $\begin{array}{l}\text { University } \\
\text { Certificate } \\
\text { or Degree }\end{array}$ & $\begin{array}{l}\text { Bachelor's } \\
\text { Degree }\end{array}$ & $\begin{array}{l}\text { Certificate, } \\
\text { Diploma } \\
\text { or Degree } \\
\text { Above } \\
\text { Bachelors }\end{array}$ \\
\hline
\end{tabular}

